\title{
CHEMICAL AND STRUCTURAL CHANGES IN POPLAR WOOD UPON STEAM TREATMENT AT CONSTANT TEMPERATURE AND PRESSURE CONDITIONS FOR DIFFERENT TIME INTERVALS
}

\author{
SHARAD RAGHUVANSHI, HINA KHAN, VAISHALI SAROHA, ASHISH KADAM and \\ DHARM DUTT \\ Department of Paper Technology, Indian Institute of Technology, \\ Roorkee, 247667, Uttarakhand, India \\ $₫$ Corresponding author: D.Dutt,dharm.dutt@pt.iitr.ac.in
}

Received June 29, 2021

Technology advancement has helped in the development of high-throughput equipment for the analysis of raw material in paper industries. In this research, we have used some advanced techniques to analyze the pore size, structural and chemical changes, and cellulose crystallinity of poplar wood pretreated with steam at constant temperature and pressure conditions for different treatment time. Samples were analyzed by the nitrogen adsorption test, Fourier-transform infrared spectroscopy - attenuated total reflectance (FTIR-ATR), X-ray diffraction (XRD), and field scanning electron microscopy (FE-SEM). Slit-shaped pores were formed, with a diameter of $2.12 \mathrm{~nm}$, after 30 minutes of treatment. FTIR results revealed the degradation of the lignin skeleton through the formation of guaiacyl and syringyl units and deformation in the cellulose and hemicelluloses structure. The crystallinity index $(C I)$ increased upon steam treatment for up to $15 \mathrm{~min}$, but after that, a drop in the $C I$ was observed. The crystallite thickness $\left(d_{200}\right)$ increased after 15 min of treatment, due to the rearrangement of cellulose chains. However, a further increase in steam treatment duration to 30 min resulted in a decline of $d_{200}$, followed by an increase in the cellulose II crystalline region and $d_{020}$. The steam treatment duration of 15-30 min was found to be a critical time interval, which led to increases in the number of mesopores, $C I, d_{200}$, and the cellulose II region in the poplar wood.

Keywords: steam, lignin, cellulose, mesopores, cellulose crystallinity

\section{INTRODUCTION}

Wood is a natural and renewable resource found abundantly on the earth crust and used as a raw material in a variety of industries, from furniture manufacture to construction, fuel, decorative and household items etc. The composition of wood is based on three main components, i.e. cellulose ( 70\%), lignin ( 20\%) and hemicelluloses $(\sim 10 \%)$. These components are responsible for the cell wall composition. Wood cells are made up of vertical cells, i.e., tracheids or vessel elements and horizontal ray cells joined by pits for the transportation of water. The wood cells consist of the middle lamella, primary wall, S1, S2, and S3 layers, which are made of lignin, hemicelluloses and cellulose. Due to the tough layers of lignin around the middle lamella and primary wall, the porosity is very low, not enough for enzymes or polymeric molecules to penetrate and reach the S1, S2, and
S3 layers. ${ }^{1,2}$ Therefore, different pretreatments of wood have been deemed necessary.

Steam treatment has been found to be effective at a high temperature, of $160{ }^{\circ} \mathrm{C}$, causing permeability of gases and moisture, and also resulting in the breakdown of cellulose chains. ${ }^{3}$ It has been reported that the breakdown of hemicelluloses also depends on the reaction time and the pressure in the reactor. ${ }^{4}$ High temperature favours the degradation of S2 and S3 layers, but the steam at constant temperature degrades only the lignin, pectin layer of the middle lamella, and lignin-hemicellulose cross-links in the primary wall cause an increase in the pore diameter in the cell wall. ${ }^{5,6}$

Previous research has reported that the steam explosion pretreatment of poplar chips at controlled temperature and pressure conditions has improved the cellulase hydrolysis yield. ${ }^{7} \mathrm{~A}$ 
possible explanation could be the increase in the number of nanopores in poplar chips due to the removal of the hemicellulose fraction. In other studies, steam explosion treatment of poplar chips at high temperature $\left(190{ }^{\circ} \mathrm{C}\right)$ enhanced the enzyme hydrolysis yield. ${ }^{8,9}$ Similarly, when Eucalyptus wood chips were subjected to steam treatment, a decrease in the extractives content was observed due to the partial removal of lignin and hemicelluloses fraction that had occurred during the preceding treatment. $^{10}$ These mentioned research works have demonstrated the effectiveness of steam explosion and steam treatment at higher temperature and pressure, but did not examine the effects of such treatments on the porosity and morphological characteristics of the wood chips. Meanwhile, this knowledge is imperative to understand the behaviour of wood and the changes occurring at the molecular level under high temperature and pressure conditions.

In this paper, the steam treatment at constant temperature and pressure conditions was investigated to determine the changes in the porosity, structure, and chemical composition of poplar wood due to the breakdown of the pectin layer, lignin, and hemicelluloses chains. Furthermore, the effect of steam duration on crystallinity was assessed, as in earlier research, it was reported that an increase in crystallinity occurred at high temperatures. Moreover, the physical and chemical behaviour of wood at constant temperature and pressure conditions was also investigated in this research.

\section{EXPERIMENTAL}

\section{Sample preparation}

Wood logs of poplar (Populus spp.) were collected from a timber manufacturer, Saharanpur (India). Wood specimens (dimensions: $30 \mathrm{~mm}(\mathrm{~L}) \times 20 \mathrm{~mm}(\mathrm{~T}) \times 20$ $\mathrm{mm}(\mathrm{R}))$ were placed into an automated laboratory autoclave at $120 \pm 1{ }^{\circ} \mathrm{C}$ and $103.4 \mathrm{kPa}$ pressure (longitudinally) for different time intervals, i.e., 15, 30, 60 and $90 \mathrm{~min}$. Samples were allowed to cool down in the autoclave until the temperature reached room temperature. Samples were stored at equilibrium moisture content close to $11-12 \%$ in a glass container at $20 \pm 1{ }^{\circ} \mathrm{C}$ and relative humidity of $65 \%$ for 10 days in a conditioned room.

Treated and untreated samples were cut into small wood sticks (dimensions: $6 \mathrm{~mm}$ longitudinally, $2 \times 2$ $\mathrm{mm}^{2}$ cross-sectionally) for porosity measurement. The sticks were treated with $80 \%, 90 \%, 95 \%$ and $100 \%$ ethanol for $5 \mathrm{~min}$ each to remove residual moisture. Using a microtome, the samples were then sliced to $200 \mu \mathrm{m}$ thickness in the radial direction for examination by FE-SEM (TESCAN MIRA 3), operating at $5 \mathrm{kV}$ and 1-10 kx. Samples were prepared as described above and then powdered in a ball-mill (Retsch, Germany) operated (for $15 \mathrm{~min}$ ) at a frequency of $5 \mathrm{~Hz}$ to a final fineness of $\sim 5 \mu \mathrm{m}$ for Xray diffractometry and FTIR-ATR (spectra range $4000-800 \mathrm{~cm}^{-1}$ at a resolution of $4 \mathrm{~cm}^{-1}$ ) studies.

\section{Nitrogen adsorption test and $\mathrm{X}$-ray diffraction}

The nitrogen adsorption test was performed using a surface area analyzer (Autosorb iQ USA) at $77.35 \mathrm{~K}$. Dehydrated samples (each $\sim 1.0 \mathrm{~g}$ ) were degassed at 80 ${ }^{\circ} \mathrm{C}$ for $12 \mathrm{~h}$ under high vacuum conditions $\left(<10^{-5} \mathrm{~Pa}\right)$ to remove any moisture or impurities from the samples. The nitrogen adsorption isotherm was obtained using AsiQWin 2.0 Software. The total pore volume $\left(\mathrm{V}_{\mathrm{T}}\right)$ was calculated from the volume of the nitrogen gas adsorbed $\left(\mathrm{V}_{\mathrm{N}}\right)$ at a relative pressure of 0.99 . The effects of relative gas pressure on wood samples were neglected for the measurement. The shape of the pores was determined by hysteresis loops. The BrunauerEmmett-Teller surface area $\left(\mathrm{S}_{\mathrm{BET}}\right)$ was calculated from a multi-point BET plot. ${ }^{11}$ The pore size distribution was calculated by the Barrett-Joyner-Halenda (BJH) method and the Density Functional Theory (DFT) method. ${ }^{12,13}$ The X-ray diffractogram was obtained using XRD (RIGAKU ULTIMA IV) with a $\mathrm{Cu}-\mathrm{K \alpha}$ radiation source $(\lambda=1.5406 \AA)$, operating at $40 \mathrm{kV}$ and $30 \mathrm{~mA}$, with the $2 \theta$ range from $5^{\circ}$ to $40^{\circ}$ and a scan rate of $4 \% \mathrm{~min}$. The crystallinity index $(C I)$ was calculated by the peak area method (Eq. 1) ${ }^{14}$ and crystallite thickness $d(h k l)$ was calculated using the Scherrer equation (Eq. 2): ${ }^{15}$

$$
\begin{aligned}
& C I=\frac{A_{c}}{A_{c+a}} \times 100 \\
& d(h k l)=\frac{K \lambda}{\beta \cos \theta}
\end{aligned}
$$

where $C I$ is the crystallinity index, and $A_{c}$ is the area of the crystalline region, and $A_{c+a}$ is the total area of the amorphous and crystalline region. $d(h k l)$ is crystallite thickness, $K$ is the Scherrer constant $(K=0.9), \lambda$ is the $\mathrm{X}$-ray wavelength, $\beta(2 \theta)$ is the peak full width at half of maximum intensity (FWHM) (in radians) obtained by Origin Pro 2019b, when peak fitting was done with the Gaussian function, and $\theta$ is the angle of diffraction of the peak.

\section{Statistical analysis}

The ANOVA analysis was performed with the data from porosity and $C I$ analysis, using Graph Pad v9.0 program (GraphPad Software Inc., USA). The statistical least-significance-difference test was carried out to test the significant difference between the mean values of the data obtained for treated and untreated samples, at a confidence limit $p<0.05$. The average value was calculated from triplicates. 


\section{RESULTS AND DISCUSSION \\ Nitrogen adsorption test}

The nitrogen adsorption isotherm (plotted between volume of gas adsorbed $\left(\mathrm{V}_{\mathrm{N}}\right)$ and relative pressure $\left.\left(\mathrm{P} / \mathrm{P}_{0}\right)\right)$ of untreated wood was intermediate between type II and type IV isotherms, referred to as mesoporous material (2$50 \mathrm{~nm}$ ), according to the nitrogen adsorption isotherm created by IUPAC (International Union of Pure and Applied Chemistry) (Fig. 1a). The symbols $S_{1}, S_{2}, S_{3}$ and $S_{4}$ represent the samples at different steam processing times, i.e., 15, 30, 60 and $90 \mathrm{~min}$, respectively. The hysteresis curve showed that the mesopores are of $\mathrm{H} 4$ type in untreated wood, of $\mathrm{H} 3$ type (slit-shaped) in sample $S_{1}$ and of $\mathrm{H} 4$ type (narrow slit-shaped) in sample $S_{2}$. After the treatment, the wood samples adsorbed more nitrogen gas. However, an increase in the treatment time to $30 \mathrm{~min}$ significantly affected the physio-sorption process. After $30 \mathrm{~min}$, no adsorption of nitrogen gas occurred. It was assumed that the treatment time affected the pores of the wood, which causes an increase in gas permeability into the wood.

The graphs between differential pore volume distributions $\mathrm{dV}(\mathrm{d})$ or $\mathrm{dV} / \mathrm{d} D$ and pore diameter
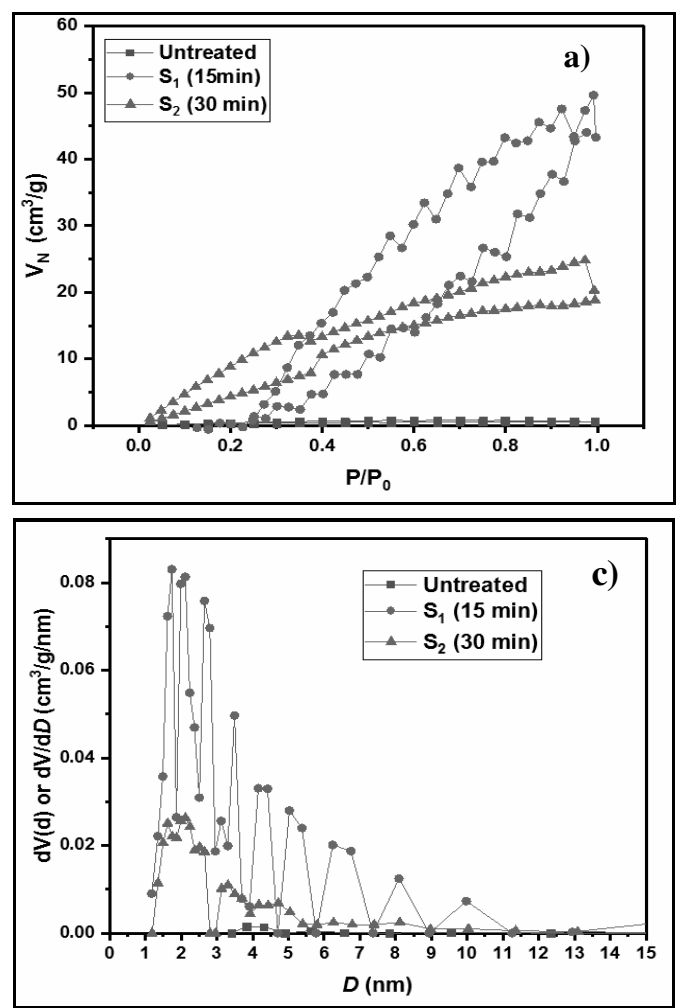

$(D)$ for untreated and treated wood are plotted in Figure $1(\mathrm{c}, \mathrm{d})$. The pore size distribution showed a sharp broad peak between $1.5 \mathrm{~nm}$ and $3 \mathrm{~nm}$. The untreated sample had slit-shaped pores with a diameter of $3.82 \mathrm{~nm}(>2 \mathrm{~nm})$. However, when the steam treatment was applied for $15 \mathrm{~min}$, the peak intensities showed a drastic increase in the area of the peaks, indicating an increase in the number of pores, a decrease in the pore size of wood (shifting to microporous), and an increase in surface area (Table 1). Whereas after $30 \mathrm{~min}$ of treatment, a noticeable change in the peaks was observed as a broadening of the peak intensities, which suggested a large number of pores with an average pore diameter of $2.12 \mathrm{~nm}$ had formed. Therefore, the decrease in the number of micropores appeared as an increase in the number of mesopores with more steam penetration. Thus, the intensities of the peaks of the samples were in the order: $S_{1}>S_{2}>$ Untreated, suggesting the effectiveness of treatment duration (Fig. 1c). However, the steam penetration also clogged the mesopores by condensed water uptake. The pore width $(W)$ was increased to $3.38 \mathrm{~nm}$ after $15 \mathrm{~min}$ of treatment, but later it decreased after $30 \mathrm{~min}$.
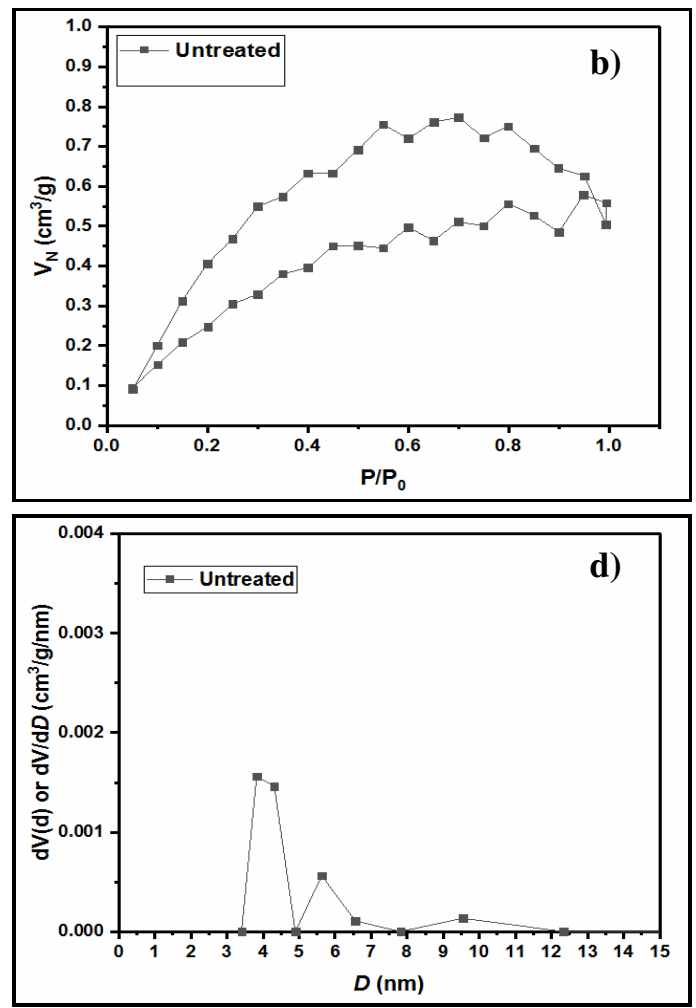

Figure 1: Nitrogen adsorption-desorption isotherm of $(a, b)$ treated and untreated wood; $(c, d)$ pore size distribution of treated and untreated wood 
Table 1

Nitrogen adsorption test results by BET, DFT and BJH methods

\begin{tabular}{|c|c|c|c|c|c|}
\hline Samples & $\begin{array}{l}\text { Pore width } \\
\text { (W) } \\
\text { (DFT) } \\
(\mathrm{nm})\end{array}$ & $\begin{array}{c}\text { Pore volume } \\
\left(\mathrm{V}_{\mathrm{T}}\right) \\
(\mathrm{BJH}) \\
\left(10^{-9} \mathrm{~m}^{3} / \mathrm{g}\right)\end{array}$ & $\begin{array}{c}\text { Pore diameter } \\
(D) \\
(\mathrm{BJH}) \\
(\mathrm{nm})\end{array}$ & $\begin{array}{c}\text { Surface area } \\
\text { (SA) (BJH) } \\
\left(\mathrm{m}^{2} / \mathrm{g}\right)\end{array}$ & $\begin{array}{c}\text { Specific } \\
\text { surface area } \\
\left(\mathrm{SSA}_{\mathrm{BET}}\right) \\
\left(\mathrm{m}^{2} / \mathrm{g}\right)\end{array}$ \\
\hline & $2.76^{\mathrm{a}}$ & $1.01^{\mathrm{a}}$ & $3.82^{\mathrm{a}}$ & $0.49^{\mathrm{a}}$ & $1.55^{\mathrm{a}}$ \\
\hline Untreated & $(0.06)$ & $(0.09)$ & $(0.03)$ & $(0.01)$ & $(0.04)$ \\
\hline & $3.38^{b}$ & $210^{b}$ & $1.74^{b}$ & $263.64^{b}$ & $33.29^{b}$ \\
\hline$S_{1}$ & $(0.02)$ & $(10.0)$ & $(0.02)$ & $(0.09)$ & $(0.18)$ \\
\hline & $2.18^{c}$ & $60^{c}$ & $2.12^{c}$ & $84.60^{c}$ & $30.20^{\mathrm{c}}$ \\
\hline $\mathrm{S}_{2}$ & $(0.02)$ & $(0.9)$ & $(0.04)$ & $(0.07)$ & $(0.02)$ \\
\hline $\mathrm{S}_{3}$ & NA & NA & NA & NA & NA \\
\hline $\mathrm{S}_{4}$ & NA & NA & NA & NA & NA \\
\hline$P$ value & $<0.0001$ & $<0.0001$ & $<0.0001$ & $<0.0001$ & $<0.0001$ \\
\hline $\mathrm{R}^{2}$ value at $\mathrm{p}<0.05$ & 0.995 & 0.994 & 0.999 & 1.0 & 1.0 \\
\hline
\end{tabular}

"NA means no adsorption of nitrogen gas occurred; ${ }^{\mathrm{a}-\mathrm{c}}$ indicate the statistical difference between the sampling positions at $\mathrm{p}<0.05$; values in brackets are standard deviation

It was assumed that the polysaccharide chains arranged so as to occupy the minimum space

A significant change was observed in the total pore volume $\left(\mathrm{V}_{\mathrm{T}}\right)$ and BET specific surface area $\left(\mathrm{SSA}_{\mathrm{BET}}\right)$ after the steam treatment (Table 1). The $\mathrm{V}_{\mathrm{T}}$ and $\mathrm{SSA}_{\mathrm{BET}}$ of the wood cells increased after 15 min of treatment, but were found to reduce after $30 \mathrm{~min}$ of treatment. The $\mathrm{V}_{\mathrm{T}}$ and $\mathrm{SSA}_{\mathrm{BET}}$ values of untreated wood were $1 \times 10^{-9} \mathrm{~m}^{3} / \mathrm{g}$ and $1.55 \mathrm{~m}^{2} / \mathrm{g}$, respectively. The $\mathrm{V}_{\mathrm{T}}$ value of treated wood increased by $210 \%$, while $\mathrm{SSA}_{\mathrm{BET}}$ increased 20 -fold after 15 min of treatment. However, the values of $\mathrm{V}_{\mathrm{T}}$ and $\mathrm{SSA}_{\mathrm{BET}}$ decreased by $67.9 \%$ and $9.28 \%$, respectively, for treated wood after 30 min. The influence of the steam treatment on $\mathrm{SSA}_{\mathrm{BET}}$ was quite similar to that on $\mathrm{V}_{\mathrm{T}}$ of the wood. The $S_{3}$ and $S_{4}$ samples showed a negative adsorption isotherm, meaning that no adsorption of gas occurred on the samples. The possible reasons for this could be the increase in the gaseous permeability, condensed water uptake because of the capillary action in wood cells, and the increase in the number of mesopores. ${ }^{3}$

For the untreated sample, no variation in the features of the pit membrane (PM) was observed (Fig. 2a, 2b). The PM was seen as intact in untreated wood, without any deformation in morphological structure. However, significant deformation in the PM was observed after $15 \mathrm{~min}$ and $30 \mathrm{~min}$ of treatment because of its rupturing (Fig. 2e, 2f). After 60 min of treatment, the pores on the PM and primary wall (PW) were filled with condensed water (Fig. 2g). The complete rupture of PM, the disappearance of margo (M) and torus $(\mathrm{T})$, and the degradation of secondary when the pore diameter increased after $30 \mathrm{~min}$ of treatment.

cell walls were observed after 90 min of treatment (Fig. 2h). It suggested that the increase in the duration of the steam treatment had an adverse effect on the structure of the cell wall and pore size of the wood, which resulted in fluid and gas permeability in the wood. Subsequently, morphological changes in PM and secondary walls in the wood cells were permanently fixed by further increase in the steam treatment time beyond $30 \mathrm{~min}^{3}$

\section{Morphological changes Changes in chemical composition}

Fourier transform infrared spectroscopy was used to analyze the changes in the chemical composition, by visualizing the peaks of crystalline cellulose at $1316 \mathrm{~cm}^{-1}$ and $1336 \mathrm{~cm}^{-1}$ due to the vibrations in $\mathrm{CH}_{2}$ bonds in crystalline cellulose and hemicelluloses (Fig. 3a). The peak intensities were maximum for the samples treated for $15 \mathrm{~min}$ and $90 \mathrm{~min}$, which suggested that the cellulose chains were affected after $15 \mathrm{~min}$ of treatment. However, after $30 \mathrm{~min}$, the peak intensity of the $\mathrm{CH}_{2}$ bands reduced due to a decrease in absorbance, which confirmed the degradation of cellulose and hemicelluloses. The bands at $2840 \mathrm{~cm}^{-1}$ and $2940 \mathrm{~cm}^{-1}$ determined the structural, compositional, and crystallinity changes in the treated wood (Fig. 3d) ${ }^{16}$ In this case, the crystallinity peak at $2840 \mathrm{~cm}^{-1}$ and 2940 $\mathrm{cm}^{-1}$ increased after $15 \mathrm{~min}$ of treatment, and variably decreased with further increase in treatment duration. 

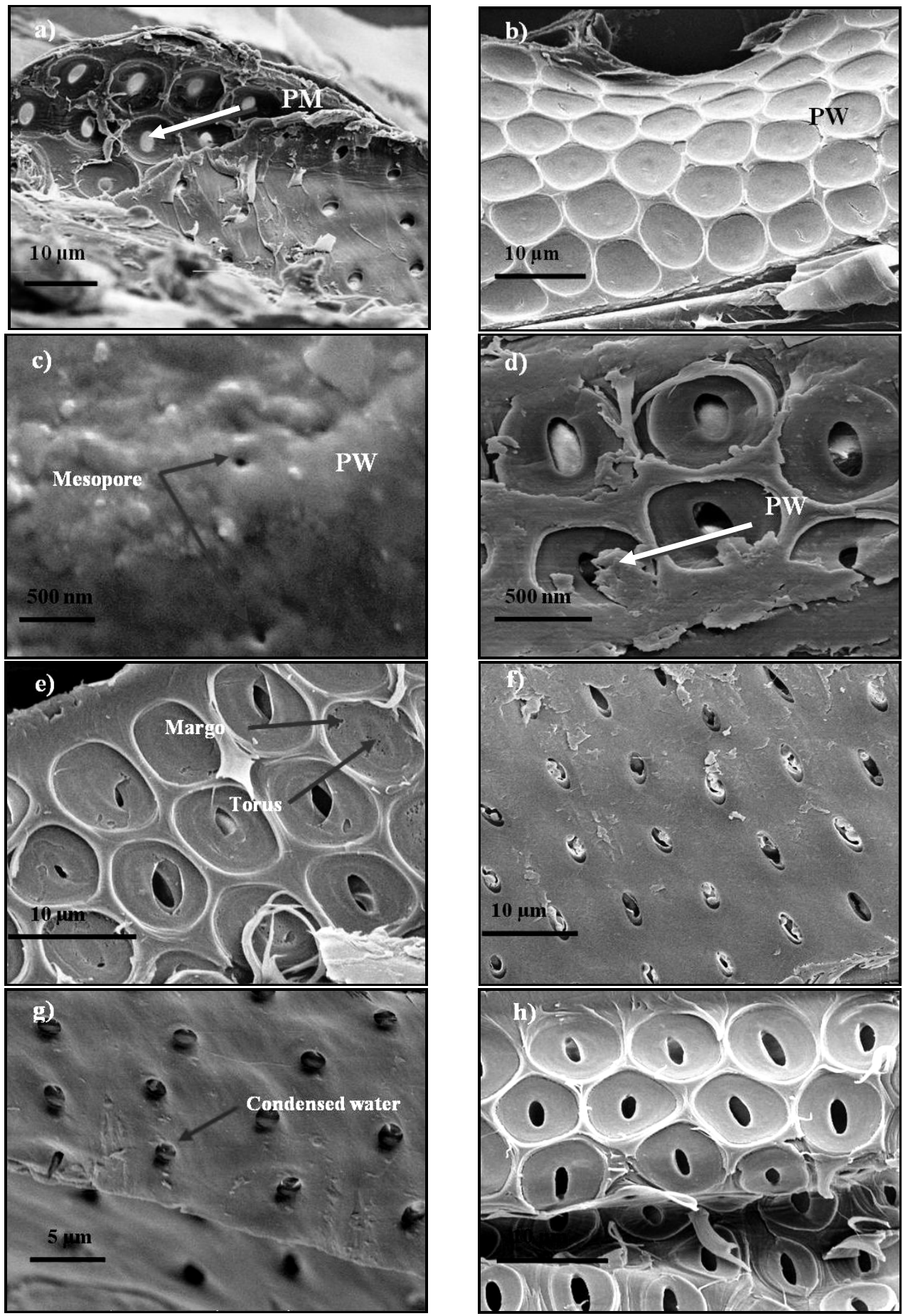

Figure 2: Morphological changes after steam treatment $(\mathrm{a}, \mathrm{b})$ untreated wood with intact pit membrane (PM); (c) pores on the primary wall (PW); (d) peel of the primary wall; pit membrane degradation after (e) 15 min; (f) $30 \mathrm{~min}$; (g) $60 \mathrm{~min}$; (h) $90 \mathrm{~min}$

The bands between $1700 \mathrm{~cm}^{-1}$ and $1750 \mathrm{~cm}^{-1}$ reflect the $\mathrm{C}=\mathrm{O}$ stretching in functional groups (esters, ketones, aldehydes, carbonyls, and carboxylic acids) of lignin and hemicelluloses. ${ }^{17}$ This indicated that $15 \mathrm{~min}$ of steam treatment significantly increased the number of $\mathrm{C}=\mathrm{O}$ bonds in lignin and hemicellulose chains (Fig. 3a). High temperature favours the degradation of lignin and increases the number of $\mathrm{C}=\mathrm{O}$ bonds. ${ }^{5}$ The band at 1596 and $1505 \mathrm{~cm}^{-1}$ showed the $\mathrm{C}=\mathrm{O}$ and $\mathrm{C}=\mathrm{C}$ 
stretch in the benzene ring of the lignin in the following order: $60 \mathrm{~min}>15 \mathrm{~min}>90 \mathrm{~min}>30$ $\min >$ untreated $(0 \mathrm{~min})$, due to the changes in the guaiacyl and syringyl units (Fig. 3c). ${ }^{17}$ The degradation of methoxyl groups of the guaiacyl and syringyl units in lignin increased the absorbance peak of the band at $1505 \mathrm{~cm}^{-15}$.
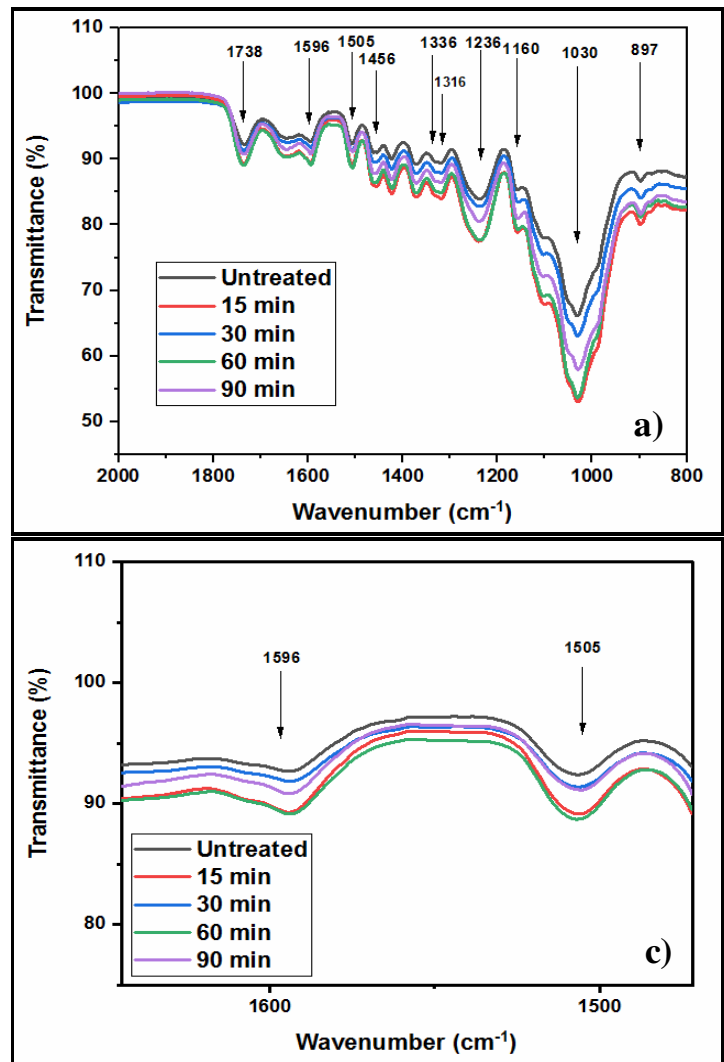

The band at $1160 \mathrm{~cm}^{-1}$ and $1030 \mathrm{~cm}^{-1}$ showed an increase in signal intensity due to the vibrations in $\mathrm{C}-\mathrm{O}-\mathrm{C}$ bonds of the cellulose and hemicelluloses. This suggested that the steam treatment for $15 \mathrm{~min}$ was enough to cause changes in the number of $\mathrm{C}-\mathrm{O}-\mathrm{C}$ bonds, leading to deformation in the cellulose and hemicellulose structure. ${ }^{18,5}$
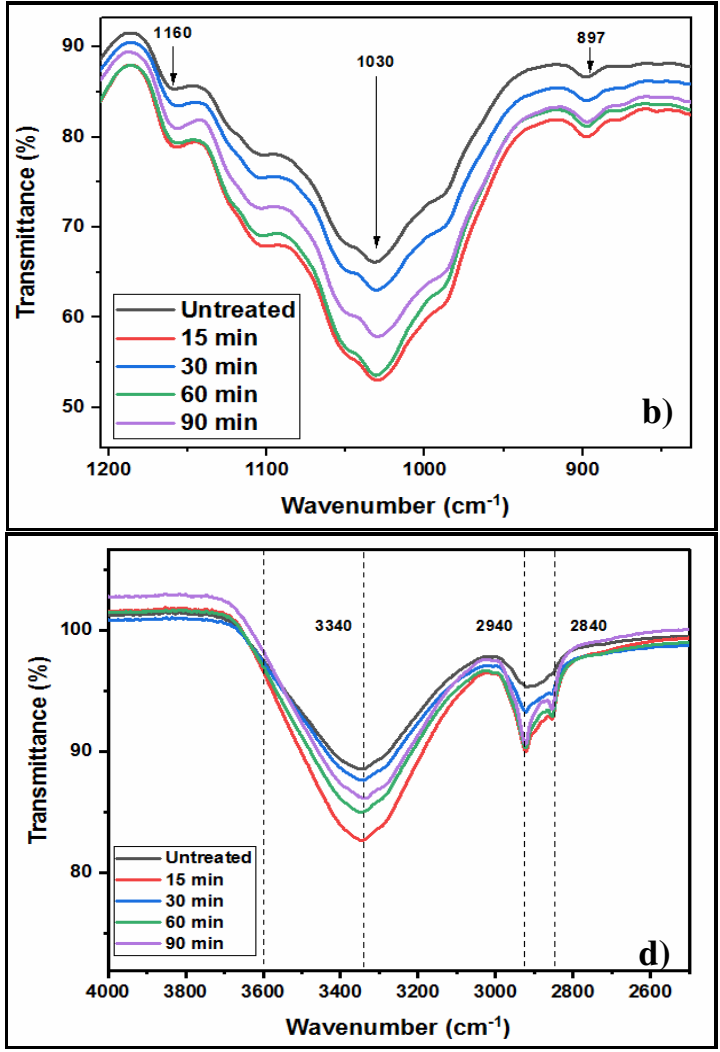

Figure 3: FT-IR spectra (a) treated and untreated wood; (b) cellulose and hemicellulose region 1160-897 $\mathrm{cm}^{-1}$; (c, d) lignin skeleton region $1590-1510 \mathrm{~cm}^{-1}$ and $3300-3600 \mathrm{~cm}^{-1}$

Table 2

Chemical changes occurring upon steam treatment at constant temperature and pressure conditions

\begin{tabular}{|c|c|c|}
\hline $\begin{array}{l}\text { Wavenumber } \\
\left(\mathrm{cm}^{-1}\right)\end{array}$ & Chemical changes & Ref. \\
\hline 1316 and 1336 & $\begin{array}{c}\mathrm{CH}_{2} \text { wagging vibrations in crystalline cellulose and to } \mathrm{OH} \text { in-plane bending of } \\
\text { amorphous cellulose }\end{array}$ & {$[5]$} \\
\hline 1738 & $\mathrm{C}=\mathrm{O}$ stretching vibrations in the $\mathrm{O}=\mathrm{C}-\mathrm{OH}$ group of a glucuronic acid unit of xylan & {$[3,17]$} \\
\hline 1596 & $\mathrm{C}=\mathrm{O}$ stretch of lignin skeleton & [17] \\
\hline 1456 & $\mathrm{CH}_{2}$ symmetric bending on the xylose ring, xylan backbone & \\
\hline 1236 & $\mathrm{C}-\mathrm{O}$ stretching in the $\mathrm{O}=\mathrm{C}-\mathrm{O}$ group in xylan & {$[5]$} \\
\hline 2840 and 2940 & Symmetric $\mathrm{CH}_{2}$ stretching and asymmetric $\mathrm{CH}_{2}$ stretching & [16] \\
\hline 3340 & Lignin intra-molecular $\mathrm{H}$-bonds and $\mathrm{OH}$ stretching of alcohols and phenols & [5] \\
\hline 1030 & Cellulose and hemicellulose deformation & {$[18,5]$} \\
\hline 1160 & $\mathrm{C}-\mathrm{O}-\mathrm{C}$ vibrations in cellulose and hemicelluloses & {$[18,5]$} \\
\hline 1505 & $\mathrm{C}=\mathrm{C}$ aromatic skeletal vibrations stretching of the benzene ring in lignin & [23] \\
\hline 897 & $\begin{array}{c}\text { Deformation of } \mathrm{C}_{1}-\mathrm{H} \text { of glucose ring in cellulose and hemicelluloses, } \beta(1-4) \\
\text { glycosidic bonds breakdown }\end{array}$ & {$[19]$} \\
\hline
\end{tabular}


Poplar wood

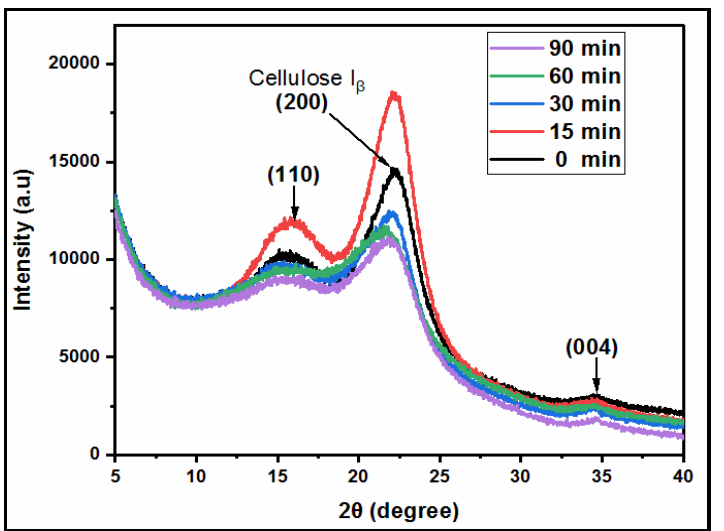

Figure 4: X-ray diffractograms of untreated and steam-treated poplar wood

Cellulose chains began to interact with each other through the $\mathrm{C}-\mathrm{O}-\mathrm{C}$ linkage, which was observed as an increase in the absorption of $\mathrm{C}-\mathrm{O}-$ $\mathrm{C}$ bonds after $15 \mathrm{~min}$. The band at $897 \mathrm{~cm}^{-1}$

Deformation of cellulose at $897 \mathrm{~cm}^{-1}$ can be seen as an increase in the amorphous cellulose and a decrease in cellulose crystallinity. ${ }^{19}$ In this case, after $15 \mathrm{~min}$ of treatment, the increase in the absorbance peak at $897 \mathrm{~cm}^{-1}$ was observed, which signified an increase in cellulose crystallinity (Fig. 3b). Later, it variably changed with further increase in treatment duration. Table 2 summarizes the chemical changes that occurred during the steam treatment.

\section{Changes in cellulose crystalline structure}

The structural changes in the cellulose structure after the steam treatment at constant temperature and pressure conditions was studied using X-ray diffractometry. The X-ray diffractograms of treated and untreated wood were plotted in Figure 4. The native form of cellulose found in nature is cellulose $I_{\beta}$ form, which is common in every wood type. Both crystalline and amorphous cellulose is present in the cell walls of higher plants. ${ }^{20,21}$ Cellulose $\mathrm{I}_{\beta}$ has parallel crystalline fibrils chains. ${ }^{22}$ In the X-ray diffractogram, the untreated wood samples showed three peaks at $16.5^{\circ}, 22.14^{\circ}$, and $34.6^{\circ}$, which correspond to the planes (110), (200), and (004), respectively. ${ }^{23}$ The $2 \theta$ angle shift in the plane (200) from $22.14^{\circ}$ to $21.8^{\circ}$ corresponds to cellulose II, and the shift to $20.7^{\circ}$ corresponds to the cellulose III polymorph.

After steam treatment for 15 min, a significant increase in the peak intensity of the planes (200) and (110) was observed. The plane (200) and plane (110) correspond to the diameter of the crystalline cellulose chains. It was suggested that indicated the glucose ring stretching vibration and deformation in the cellulose structure, with the breakdown of glycosidic bonds.

cellulose and hemicellulose chains were not much negatively affected after $15 \mathrm{~min}$ of steam treatment, due to the rearrangement or reordering of cellulose chains in the more crystalline region. $^{24}$ However, the plane (004) that corresponds to the length of microfibrils experienced no change after the treatment, which suggested that the length of cellulose chains remained unaffected during the steam treatment up to 90 min. $^{24}$

The crystallinity index $(C I)$ was calculated as the area of the crystalline region to the total area (amorphous region + crystalline region). Crystallinity changes were observed in the treated wood. With respect to the data given in Table 3, the $C I$ of treated wood increased by $0.65 \%$ after 15 min of treatment. However, further increase in the treatment time resulted in a reduction of the CI by $2.9 \%$ for $30 \mathrm{~min}, 3.81 \%$ for $60 \mathrm{~min}$, and $5.39 \%$ for $90 \mathrm{~min}$, compared to the steam treatment for $15 \mathrm{~min}$.

ANOVA analysis was carried out to investigate the statistical difference between the $C I$ with the increase in treatment duration. There was a significant difference between the sampling groups at $p<0.05$ and a significant influence of treatment time on $C I$, as shown in Table 3 . The average crystallite size $\left(d_{200}\right)$ was found to be 2.09 $\mathrm{nm}$ for the untreated wood $(0 \mathrm{~min})$, while steam treatment significantly affected the average crystallite size (Table 3$)$. The crystallite size $\left(d_{200}\right)$ was increased in the sample treated for $15 \mathrm{~min}$, but decreased later for 30,60, and $90 \mathrm{~min}$, with a peak shift to $21.8^{\circ}$, which corresponds to the plane $(020)$ of the cellulose II polymorph. The 
average crystallite size $\left(d_{020}\right)$ of the samples treated for 15,30 , and $90 \mathrm{~min}$ was calculated as $1.89 \mathrm{~nm}, 1.52 \mathrm{~nm}$, and $2.05 \mathrm{~nm}$, respectively. The native state of cellulose was not found to be crystalline. ${ }^{25}$ Upon increasing the duration of the steam treatment, the cellulose chains begin to organize themselves into a more crystalline region. However, the continuous increase in steam treatment duration leads to the degradation of cellulose chains, and a shift of the $2 \theta$ value to the amorphous or semi-crystalline region, which was found to be consistent with the regular decrease of $C I$ in samples treated for 30,60, and $90 \mathrm{~min}$.

Table 3

Changes in the crystallinity and crystallite size for the different steam processing time

\begin{tabular}{lccccccc}
\hline $\begin{array}{l}\text { Processing time } \\
(\mathrm{min})\end{array}$ & 0 & 15 & 30 & 60 & 90 & $\mathrm{P}$ value & $\begin{array}{c}\mathrm{R}^{2} \text { value at } \\
\mathrm{p}<0.05\end{array}$ \\
\hline$C I(\%)$ & $81.84^{\mathrm{a}}$ & $82.49^{\mathrm{b}}$ & $79.59^{\mathrm{c}}$ & $78.68^{\mathrm{d}}$ & $77.10^{\mathrm{e}}$ & $<$ & 0.995 \\
$($ Std. dev. $)$ & $(0.27)$ & $(0.10)$ & $(0.11)$ & $(0.09)$ & $(0.02)$ & 0.0001 & \\
$d(\mathrm{~nm})$ & $2.09^{\mathrm{a}}$ & $2.15^{\mathrm{a}}$ & $1.89^{\mathrm{b}}$ & $1.52^{\mathrm{c}}$ & $2.05^{\mathrm{a}, \mathrm{b}}$ & $<$ & 0.930 \\
$($ Std. dev. $)$ & $(0.06)$ & $(0.02)$ & $(0.11)$ & $(0.04)$ & $(0.07)$ & 0.0001 & \\
\hline
\end{tabular}

${ }^{\mathrm{a}-\mathrm{e}}$ the same letter in the same row indicates no significant difference between the sampling positions at $\mathrm{p}<0.05$; Std. dev. stands for standard deviation

\section{CONCLUSION}

Steam treatment at constant temperature and pressure conditions affects the mesopore diameter and crystallinity of wood because of the rearrangement in the chemical structure and the cellulose chains. However, as the treatment time increased, the lignin and xylan residues began to degrade. The cellulose crystallinity index increased after $15 \mathrm{~min}$ of treatment and then decreased due to the degradation in cellulose chains. Degradation of PM appeared with the increase in the treatment time. However, BET isotherms showed no adsorption of gas in the wood sample treated for more than $30 \mathrm{~min}$. Due to the increase in the mesopore size, the gas and fluid permeability in wood increases, which prevents the physio-sorption of gas. Poplar wood underwent chemical and structural changes after 15 min of steam treatment at constant temperature and pressure, which was reflected in the form of degradation in the lignin skeleton, $\mathrm{CH}_{2}$ and $\mathrm{OH}$ group vibrations in crystalline and amorphous cellulose, and the degradation in the xylan backbone. This research provides a practical understanding of wood behaviour under steam treatment at high temperature and pressure for different duration, employing new highthroughput advanced techniques in paper industries.

ACKNOWLEDGEMENT: The authors wish to thank the Ministry of Human Resources and Development, Government of India, for financial support. The authors are thankful to IIT Roorkee for providing the laboratory and instrumentation facilities.

\section{REFERENCES}

1 E. Srebotnik, K. Messner and R. Foisner, Appl. Environ. Microbiol., 54, $2608 \quad$ (1988), https://doi.org/10.1128/aem.54.11.2608-2614.1988

2 C. M. Popescu, C. M. Tibirna, A. L. Manoliu, P. Gradinariu and C. Vasile, Cellulose Chem. Technol., 45, 565

(2011),

https://www.cellulosechemtechnol.ro/pdf/CCT45,9-

10(2011)/p.565-569.pdf

3 J. Guo, K. Song, L. Salmén and Y. Yin, Carbohyd. Polym., $\quad 115, \quad 207 \quad$ (2015), https://doi.org/10.1016/j.carbpol.2014.08.040

4 N. Jacquet, G. Maniet, C. Vanderghem, F. Delvigne and A. Richel, Ind. Eng. Chem. Res., 54, 2593 (2015), https://doi.org/10.1021/ie503151g

5 I. Kubovský, D. Kačíková and F. Kačík, Polymers, 12 , 485

(2020),

https://dx.doi.org/10.3390\%2Fpolym12020485

6 M. Arshadi and H. Grundberg, in "Handbook of Biofuels Production”, edited by R. Luque, J. Campelo and J. Clark, Woodhead Publishing, 2011, pp. 199-220

7 H. Wang, Z. Liu, X. Zheng, X. Pan, X. Hui et al., Carbohyd. Polym., 230, $115622 \quad$ (2020), https://doi.org/10.1016/j.carbpol.2019.115622

8 A. Galazka and J. Szadkowski, Cellulose Chem. Technol., $\quad 55, \quad 637 \quad$ (2021), https://doi.org/10.35812/CelluloseChemTechnol.2021. 55.52

9 Y. Yu, J. Wu, X. Ren, A. Lau, H. Takada et al., Renew. Sustain. Energ. Rev., 154, 111871 (2022), https://doi.org/10.1016/j.rser.2021.111871

10 R. Martin-Sampedro, M. E. Eugenio, J. A. Moreno, E. Revilla and J. C. Villar, Bioresour. Technol., 153, 236

(2014), 

Chem. Soc., 60, 309 (1938), https://doi.org/10.1021/ja01269a023

12 E. P. Barrett, L. G. Joyner and P. P. Halenda, J. Am. Chem. Soc., $\mathbf{7 3 ,} 373 \quad$ (1951), https://doi.org/10.1021/ja01145a126

13 M. Nopens, U. Sazama, S. König, S. Kaschuro, A. Krause et al., Sci. Rep., 10, 11 (2020), https://doi.org/10.1038/s41598-020-65066-1

14 E. L. Hult, T. Iversen and J. Sugiyama, Cellulose, 10, 103

(2003), https://doi.org/10.1023/A:1024080700873

15 J. I. Langford and A. J. C. Wilson, J. Appl. Crystallogr., $\quad \mathbf{1 1}, \quad 102 \quad$ (1978), https://doi.org/10.1107/S0021889878012844

16 I. Spiridon, C. A. Teaca and R. Bodîrlău, BioResources, $\quad$ 6, $400 \quad$ (2011), https://doi.org/10.15376/biores.6.1.400-413

17 B. Esteves, A. V. Marques, I. Domingos and H. Pereira, Maderas Cienc. Tecnol., 15, 245 (2013), https://dx.doi.org/10.4067/S0718221X2013005000020

18 W. Peng, L. Wang, M. Ohkoshi and M. Zhang, Cellulose Chem. Technol., 49, 756 (2015),
https://www.cellulosechemtechnol.ro/pdf/CCT9-

10(2015)/p.756-764.pdf

19 M. Akerholm, B. Hinterstoisser and L. Salmén, Carbohyd. Res., 339, $569 \quad$ (2004), https://doi.org/10.1016/j.carres.2003.11.012

${ }^{20}$ K. Ruel, Y. Nishiyama and J. P. Joseleau, Plant Sci., 193, 48 (2012), https://doi.org/10.1016/j.plantsci.2012.05.008

${ }^{21}$ H. Khan, A. Kadam and D. Dutt, Carbohyd. Polym., 229, $115513 \quad$ (2020), https://doi.org/10.1016/j.carbpol.2019.115513

22 M. Poletto, V. Pistor and A. J. Zattera, in "Cellulose - Fundamental Aspects", edited by T. G. M. Van De Ven, IntechOpen, 2013, pp. 45-68

23 W. S. Chen, H. P. Yu, Y. X. Liu, P. Chen, M. X. Zhang et al., Carbohyd. Polym., 83, 1804 (2011), https://doi.org/10.1016/j.carbpol.2010.10.040

24 J. Guo, H. Rennhofer, Y. Yin and H. C. Lichtenegger, Cellulose, 23, 2325 (2016), https://doi.org/10.1007/s10570-016-0982-2

${ }_{25}$ U. P. Agarwal, S. A. Ralph, R. S. Reiner and C. Baez, Cellulose, 23, $125 \quad$ (2016), https://doi.org/10.1007/s10570-015-0788-7 